\title{
Pengaruh DER, TATO dan NPM Terhadap Kebijakan Dividen (Studi Kasus Pada Industri Dasar dan Kimia yang Terdaftar Di Bursa Efek Indonesia (BEI) Tahun 2012-2016)
}

\author{
Iwan Firdaus \\ iwanfirdaus08179@gmail.com \\ Program Studi Manajemen, FEB, Universitas Mercu Buana \\ Putri Handayani \\ Program Studi Manajemen, FEB, Universitas Mercu Buana
}

\begin{abstract}
This research was conducted to examine the effect of Debt to Equity Ratio (DER), Total asset turnover (TATO) dan Net profit margin (NPM) to Dividend Payout Ratio (DPR). The object for this research is basic industry and chamicals listed on the Indonesia Stock Exchange in the period 2012-2016. This research was conducted using quantitative menthod with total 10 sample of research were determined by saturated sampling. Method of hypothesis testing using t-test. This research use Debt to Equity Ratio $\left(\mathrm{X}_{1}\right)$, Total asset turnover $\left(\mathrm{X}_{2}\right)$, Net profit margin $\left(\mathrm{X}_{3}\right)$ as independent variable and Dividend Payout Ratio as dependent variable. The results of this research is Total asset turnover (TATO) and Net profit margin (NPM) positive and has significant effect to Dividend Payout Ratio, while the DER negative and has no significant effect to Dividend Payout Ratio.
\end{abstract}

Keywords: Currrent ratio, Debt to Equity Ratio, Dividend Payout Ratio, Return on asset, Sales Growth

\begin{abstract}
Abstrak
Penelitian ini dilakukan untuk menguji pengaruh variabel Debt to Equity Ratio (DER), Total asset turnover (TATO) dan Net profit margin (NPM) terhadap Dividend Payout Ratio (DPR). Objek penelitian ini adalah industry dasar dan kimia yang terdaftar di Bursa Efek Indonesia periode 2012-2016. Penelitian ini dilakukan menggunakan metode kuantitatif dengan total 10 sampel penelitian yang ditentukan melalui metode sample jenuh. Metode pengujian hipotesis menggunakan uji t. Variabel yang digunakan dalam penelitian ini adalah Debt to Equity Ratio $\left(\mathrm{X}_{1}\right)$, Total asset turnover $\left(\mathrm{X}_{2}\right)$, Net profit margin $\left(\mathrm{X}_{3}\right)$, sebagai variabel independen dan Dividend Payout Ratio sebagai variabel dependen. Hasil penelitian ini adalah Total asset turnover (TATO) dan Net profit margin (NPM) berpengaruh positif dan signifikan terhadap Dividend Payout Ratio, sedangkan untuk Debt to Equity Ratio (DER) berpengaruh negatif tapi tidak signifikan terhadap Dividend Payout Ratio.
\end{abstract}

Kata Kunci: Current ratio, Debt to Equity Ratio, Dividend Payout Ratio, Return on asset, Sales Growth 


\section{PENDAHULUAN}

Menurut kebijakan moneter perbankan Indonesia pertumbuhan ekonomi Indonesia pada triwulan III tahun 2017 membaik. Pertumbuhan ekonomi Indonesia pada triwulan III tercatat 5,06\%, meningkat dibandingkan dua triwulan sebelumnya yang masing- masing 5,01\%. Membaiknya pertumbuhan ekonomi pada triwulan III 2017 diikuti dengan struktur yang berimbang seiring dengan meningkatnya kinerja ekspor dan investasi, baik pemerintah maupun swasta. Bank Indonesia memperkirakan pertumbuhan ekonomi secara keseluruhan 2017 sekitar 5,1\% dan akan terus meningkat lebih tinggi dengan kisaran 5,1-5,5\% pada 2018. (www.bi.go.id).

Berdasarkan BPS (2017) pertumbuhan ekonomi indonesia mengalami kenaikan pada tahun 2012 sebesar 6,2\% dan mengalami penurunan pada tahun 2013 sebesar 6,01\% dan tahun 2014 mengalami penurunan sebesar 5,02\%. Sedangkan tahun 2015 mengalami kenaikan 5,50\% dan semakin membaik ditahun 2016 meningkat menjadi 5,98. Sedangkan industri manufaktur mengalami pergerakan fluktuatif dan berada di bawah rata-rata pertumbuhan ekonomi indonesia. Meskipun begitu pada tahun 2014, industri manufaktur mengalami kenaikan sebesar 6,0\% diatas rata-rata pertumbuhan ekonomi indonesia.

Pada tahun 2013 kinerja ekspor indonesia mengalami penurunan dibandingkan tahun sebelumnya. Penurunan tersebut salah satunya disumbang oleh industri manufaktur seperti sektor barang karet olahan, kimia, logam dasar, elektronik, dan tekstil. Kinerja ekspor industri manufaktur tersebut sejalan dengan turunnya nilai ekspor negara-negara tujuan utama yaitu Amerika Serikat, Jepang, China,dan India (Kebijakan Monter Bank Indonesia, 2013).

Pertumbuhan perekonomian pada tahun 2014 masih menurun, hal tersebut terjadi karena adanya persepsi negatif investor asing terhadap tekanan inflasi yang sempat terjadi pasca kenaikan harga BBM bersubsidi. Berbanding terbalik dengan keadaan industri manufaktur yang mengalami kenaikan di beberapa subsektor industri, terutama industri kimia dasar, bahan kimia, dan barang dari bahan kimia sebesar 8,86 persen, industri pengolahan dan pengawetan daging, ikan, buah-buahan, sayuran, minyak, dan lemak sebesar 5,39 persen, dan industri mesin, listrik, elektronik, dan perlengkapannya sebesar 5,04 persen. Menurut Suryamin (2016), kenaikan tersebut tidak berlangsung merata karena ada sektor yang mengalami penurunan seperti industri logam dasar sebesar 1,4 persen dan industri kertas, barang dari kertas, dan cetakan sebesar 1,05 persen.

Pertumbuhan ekonomi Indonesia pada tahun 2015-2016 semakin membaik. Di tengah berbagai tantangan eksternal dan domestik, perekonomian Indonesia 2015 mencatat kinerja yang positif. Stabilitas makroekonomi dan sistem keuangan terjaga sementara momentum pertumbuhan ekonomi mulai bergulir. Terjaganya stabilitas makro ekonomi tercermin pada inflasi yang kembali pada kisaran sasarannya $4 \pm 1 \%$, defisit transaksi berjalan yang menurun ke sekitar 2\% dari PDB, nilai tukar rupiah yang terkendali terutama sejak triwulan IV 2015, dan sistem keuangan yang resilien didukung oleh kecukupan modal yang kuat. Sementara itu, pertumbuhan ekonomi yang berada pada tren melemah mulai menemukan momentum pembalikan pada semester II 2015. Menurut Kebijakan Moneter Bank Indonesia (2015-2016), pencapaian kinerja ekonomi tersebut tidak terlepas dari sinergi kebijakan yang ditempuh Bank Indonesia dan Pemerintah untuk mengawal stabilitas makroekonomi dan sistem keuangan serta mendorong proses pemulihan perekonomian.

Kebijakan dividen perusahaan tergambar pada dividend payout ratio nya yaitu persentase laba yang dibagikan dalam bentuk dividen tunai atau rasio antara dividen yang dibayarkan sebuah perusahaan (dalam satu tahun buku) dibagi dengan keuntungan bersih perusahaan (net income) pada tahun buku tersebut. Artinya besar kecilnya dividend payout ratio akan mempengaruhi keputusan investasi para pemegang saham dan disisi lain berpengaruh pada 
kondisi keuangan perusahaan. Oleh karena itu kebijakan dividen menjadi penting dalam menentukan besarnya dividend payout ratio

Tabel 1. Dividend Payout Ratio Industri Dasar dan Kimia yang Terdaftar di Bursa Efek Indonesia Tahun 2012-2016

\begin{tabular}{cclccccc}
\hline & KODE & & & & & & \\
NO & SHM & NAMA PERUSAHAAN & 2012 & 2013 & 2014 & 2015 & 2016 \\
\hline 1 & TOTO & Surya Toto Indonesia Tbk & 0,21 & 0,02 & 0,02 & 0,01 & 0,02 \\
2 & LION & Lion Metal Works Tbk & 0,18 & 0,32 & 0,42 & 0,45 & 0,05 \\
3 & LMSH & Lionmesh Prima Tbk & 0,02 & 0,10 & 0,26 & 0,49 & 0,01 \\
4 & AMFG & Asahimas Flat Glass Tbk & 0,10 & 0,10 & 0,08 & 0,10 & 0,13 \\
5 & ALKA & Alaska Industrindo & 0,23 & 0,40 & 0,20 & 0,70 & 0,12 \\
6 & CTBN & Citra Turbindo & 0,18 & 0,20 & 0,90 & 0,80 & 0,70 \\
7 & INTP & Indocement Tunggal Prakarsa & 1,01 & 0,90 & 1,03 & 1,09 & 1,10 \\
8 & CPIN & Charoen Pokphan Indonesia & 0,90 & 0,80 & 0,74 & 0,71 & 1,12 \\
9 & SMBR & Semen Bajuraja (Persero) Tbk & 1,02 & 0,98 & 1,03 & 0,95 & 0,67 \\
10 & AKPI & Argha Karya Prima Industry & 0,90 & 1,02 & 0,89 & 0,72 & 0,98 \\
& RATA-RATA DPR & 0,48 & 0,48 & 0,56 & 0,60 & 0,49 \\
\hline
\end{tabular}

Sumber: idx.co.id, data diolah (2018)

Data pada Tabel 1. Dividend Payout Ratio (DPR) Industri Dasar dan Kimia yang Terdaftar di Bursa Efek Indonesia Tahun 2012-2016 menunjukkan pergerakan DPR yang berfluktuasi, cenderung menurun pada setiap perusahaan di Industri Dasar dan Kimia yang Terdaftar di Bursa Efek Indonesia Tahun 2012-2016. Dapat diambil contoh dari Tabel 1 Perusahanaan Lion Metal Works Tbk memiliki nilai DPR yang berfluktuatif tapi cenderung mengalami kenaikan yang signifikan, ditahun 2012 nilainya adalah 0,18 lalu mengalami kenaikan yang cukup drastis menjadi 0,32 dan naik kembali ditahun berikutnya ditahun 2014 sebesar 0,42 dan 2015 0,45, namun ditahun 2016 mengalami penurunan lagi menjadi 0,05. Contoh lainnya Perusahanaan Lionmesh Prima Tbk memiliki nilai DPR yang berfluktuatif tapi cenderung mengalami kenaikan, ditahun 2012 nilainya adalah 0,02 lalu mengalami kenaikan ditahun 2013 menjadi 0,1 dan naik kembali ditahun berikutnya ditahun 2014 sebesar 0,26 dan 2015 0,49, namun ditahun 2016 mengalami penurunan lagi menjadi 0,01.

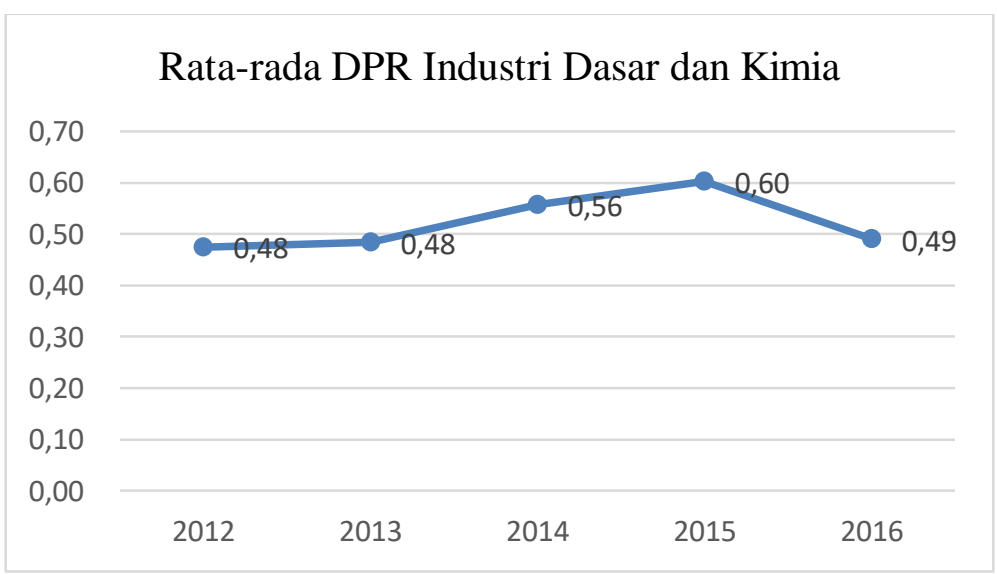

Gambar 2. Rata-rata DPR Industri Dasar dan Kimia yang Terdaftar di Bursa Efek Indonesia Tahun 2012-2016

Sumber: idx.co.id, data diolah (2018) 
Berdasarkan gambar 1. Rata-rata DPR Industri Dasar dan Kimia yang Terdaftar di Bursa Efek Indonesia Tahun 2012-2016, terlihat pergerak rata-rata industry dividend payout ratio pada industry Dasar dan Kimia yang Terdaftar di Bursa Efek Indonesia Tahun 2012-2016 terlihat menaik lambat selama 4 tahun berturut-turut dari tahun 2012-2015, tapi berikutnya pada tahun 2015 ke 2016 menurun tajam, hal ini merupakan fenomena yang menaik untuk diteliti, di mana pada saat negara sedang mengalami kenaikan ekonomi, justru DPR industri dasar dan kimia tahun 2016 menurun menjadi 0,49 atau 49\%. Hal ini pastilah sangat berdampak bagi investor di industry tersebut, dikarenakan DPR menggambarkan seberapa besar dividen yang akan diterima oleh investor pada tahun tersebut.

Berikut ini ditampilkan beberapa research gap yang berkaitan dengan kebijakan dividen yang dilakukan oleh peneliti terdahulu. Hasil Penelitian terdahulu menurut Handayani (2010) DER berpengaruh negatif dan signifikan terhadap variabel Deviden payout ratio. Penelitian Etall (2017) hasil penelitian DER berpengaruh negatif tidak signifikan terhadap Deviden Payaout Ratio, lalu hasil penelitian dari Raissa (2012) bahwa DER berpengaruh positif dan signifikan terhadap Deviden Payout Ratio dan Kurniawan (2016) mendapatkan hasil penelitian bahwa DER berpengaruh positif tidak signifikan terhadap Deviden Payout Ratio.

Berdasarkan kepada hasil Penelitian terdahulu dari Rahamawati (2014) bahwa TATO berpengaruh negatif dan signifikan terhadap variabel Deviden payout ratio. Penelitian Ari (2017) hasil penelitian TATO berpengaruh negatif tidak signifikan terhadap Deviden Payaout Ratio, lalu Janne dan Ayerza (2014) TATO berpengaruh positif dan signifikan terhadap Deviden Payout Ratio dan Kurniawan (2016) TATO berpengaruh positif tidak signifikan terhadap Deviden Payout Ratio.

Berdasarkan kepada hasil Penelitian terdahulu dari Ari (2017), bahwa NPM berpengaruh negatif dan signifikan terhadap variabel Deviden payout ratio. Penelitian Liaow (2014) memberikan hasil penelitian bahwa NPM berpengaruh negatif tidak signifikan terhadap Deviden Payaout Ratio, lalu Prasetyo dan Sampurno (2013) mendapatkan hasil penelitian bahwa NPM berpengaruh positif dan signifikan terhadap Deviden Payout Ratio dan hasil penelitian Raissa (2012) mendapatkan NPM berpengaruh positif tidak signifikan terhadap Deviden Payout Ratio

Melihat fenomena Dividend Payout Ratio (DPR) dalam kaitannya dengan rasio-rasio keuangan, maka penelitian ini diberi judul "pengaruh variabel Debt to Equity Ratio (DER), Total Asset Turnover (TATO) dan Net Profit Margin (NPM) terhadap Dividend Payout Ratio (DPR) pada industri dasar dan kimia yang terdaftar di Bursa Efek Indonesia periode 20122016".

Berdasarkan uraian-uraian diatas, diajukan pertanyaaan rumusan masalah sebagai berikut: (1) Apakah Debt to Equity Ratio (DER) berpengaruh terhadap dividend payout ratio (DPR) pada industri dasar dan kimia yang terdaftar di BEI periode 2012-2016?; (2) Apakah Total Asset Turnover (TATO) berpengaruh terhadap dividend payout ratio (DPR) pada industri dasar dan kimia yang terdaftar di BEI periode 2012-2016?; (3) Apakah Net Profit Margin (NPM) berpengaruh terhadap dividend payout ratio (DPR) pada industri dasar dan kimia yang terdaftar di BEI periode 2012-2016?

Adapun tujuan dari penelitian, antara lain: (1) Untuk mengetahui dan menganalisis pengaruh Debt to Equity Ratio (DER) terhadap dividend payout ratio (DPR) pada industri dasar dan kimia yang terdaftar di BEI periode 2012-2016; (2) Untuk mengetahui dan menganalisis pengaruh Total Asset Turnover (TATO) terhadap dividend payout ratio (DPR) pada industri dasar dan kimia yang terdaftar di BEI periode 2012-2016; (3) Untuk mengetahui dan menganalisis pengaruh Net Profit Margin (NPM) terhadap dividend payout ratio (DPR) pada industri dasar dan kimia yang terdaftar di BEI periode 2012-2016. 


\section{KAJIAN TEORI}

\section{Manajemen Keuangan}

Menurut Keown (2011) manajemen keuangan adalah hal yang berkepentingan dengan bagaimana cara menciptakan dan menjaga nilai ekonomis dari kekayaan pemilik perusahaan. Konsekuensinya, semua pengambilan keputusan harus difokuskan pada penciptaan kekayaan. Menurut Kasmir (2014) bahwa aktivitas manajemen keuangan berkaitan erat dengan pengelolaan keuangan perusahaan, termasuk lembaga yang berhubungan erat dengan sumber pendanaan dan investasi kaungan perusahaan serta instrumen keuangan.

Menurut Sutrisno (2012), bahwa manajemen keuangan atau sering disebut pembelanjaan dapat di artikan sebagai berikut: "Semua aktivitas perusahaan yang berhubungan langsung dengan usaha-usaha untuk mendapatkan dana perusahaan dengan biaya murah serta usaha untuk menggunakan dan mengalokasikan dana tersebut secara efisien". Usaha mendapatkan dana disebut dengan pembelanjaan pasif, yang berada di sisi liabilitas dan ekuitas pada neraca.

Sedangkan usaha mengalokasikan dana disebut pembelanjaan aktif yang berada di sisi aset pada neraca. Dari pengertian di atas bahwa manajemen keuangan adalah keseluruhan aktivitas perusahaan yang bersangkutan dengan usaha untuk mendapatkan dana, menggunakan dan mengalokasikan dana tersebut guna mencapai suatu tujuan yang diharapkan. Manajemen keuangan mempunyai tiga macam keputusan penting atau utama, yaitu:

1) Pengunaan dana, disebut sebagai keputusan investasi, adalah Penanaman modal dapat dilakukan pada aktiva riil ataupun aktiva keuangan. Aktiva riil merupakan aktiva yang bersifat fisik atau dapat dilihat jelas secara fisik, misalnya persediaan barang, gedung, tanah dan bangunan. Sedangkan aktiva keuangan merupakan aktiva berupa surat-surat berharga seperti saham dan obligasi. Keputusan investasi yang dilakukan perusahaan dapat dilakukan dengan beberapa langkah, yakni: pertama, manajer keuangan perlu menetapkan berapa asset secara keseluruhan (total asset) yang diperlukan dalam perusahaan. Kedua, dari asset yang diperlukan perlu ditetapkan komposisi dari asset-asset tersebut yaitu berapa jumlah aktiva tetap (fixed assets). Ketiga, untuk mencapai pemanfaatan aset secara optimal maka aset-aset yang tidak ekonomis lagi perlu dikurangi, dihilangkan atau diganti dengan aset yang baru.

2) Memperoleh dana, disebut sebagai keputusan pendanaan, adalah Keputusan pendanaan akan mempelajari sumber-sumber dana yang berada di sisi pasiva. Keputusan pendanaan meliputi beberapa hal yakni, pertama adalah keputusan mengenai penetapan sumber dana yang diperlukan untuk mendanai investasi berupa utang jangka pendek dan utang jangka panjang juga modal sendiri. Kedua, penetapan tentang perimbangan pembelanjaan yang terbaik atau sering disebut dengan struktur modal yang optimum.

3) Keputusan manajemen aset, pengalokasian dana yang digunakan untuk pengadaan dan pemanfaatan asset menjadi tanggung jawab manajer keuangan. Aktiva lancar akan didanai dari utang lancar yang jangka waktunya lebih panjang dari usia aktiva lancar dan sebagai utang jangka panjang. Aktiva tetap yang tidak disusutkan seperti tanah akan dibiayai dengan modal sendiri dan laba perusahaan atau laba ditahan, sedangkan asset yang disusutkan seperti bangunan dan mesin serta peralatan dapat dibiayai dengan utang jangka panjang dan modal sendiri.

Berdasarkan pernyataan di atas, maka peranan manajemen keuangan suatu perusahaan menjadi penting karena berkaitan dengan perolehan aset, pendanaan, dan manajemen aset dengan didasari beberapa tujuan umum. Hornee dan Wachowicz (2012). Tujuan umum manajemen keuangan adalah memaksimalkan nilai saham perusahaan, memaksimalkan kesejahteraan pemilik perusahaan, investor, kreditur, dan pihak-pihak lainya yang berkepentingan. 


\section{Rasio pembayaran dividen (dividend payout ratio)}

Menurut Bringham dan Houston (2014) Dividend Payout Ratio (DPR) adalah persentase laba yang dibayarkan dalam bentuk dividen atau rasio antara laba yang dibayarkan dalam bentuk dividen dengan total laba yang tersedia bagi pemegang saham. Dividend payout ratio didefinisikan sebagai besarnya rasio yang harus ditentukan perusahaan untuk membayar dividen kepada para pemegang saham setiap tahun yang dilakukan berdasarkan besar kecilnya laba berseih setelah pajak. Dividend payout ratio merupakan indikasi atas persentase jumlah pendapatan yang diperoleh yang didistribusikan kepada pemilik atau pemegang saham dalam bentuk kas. Secara matematis rumus dividend payout ratio (DPR) dapat dirumuskan sebagai berikut:

$$
\text { Dividend Payout Ratio }=\frac{\text { Dividen per lembar }}{\text { Laba per lembar }}
$$

\section{Rasio Keuangan}

1) Debt to Equity Ratio (DER)

Menurut Brigham dan Houston (2014) Debt to Equity Ratio adalah Rasio yang menggambarkan perbandingan utang dan ekuitas dalam pendanaan perusahaan dan menunjukan kemampuan modal sendiri perusahaan tersebut untuk memenuhi seluruh kewajibannya. Menurut Keown (2011) menjelaskan bahwa Debt to Equity Ratio menujukkan perbandingan antara utang dengan modal sendiri, sedangkan menurut Fahmi (2009) mendefinisikan Debt to Equity Ratio adalah rasio yang menggambarkan perbandingan utang dan ekuitas dalam pendanaan perusahaan dan menujukkan kemampuan modal sendiri perusahaan tersebut untuk memenuhi seluruh kewajibannya.Secara matematis rumus Debt to Equity Ratio (DER) dapat dirumuskan sebagai berikut:

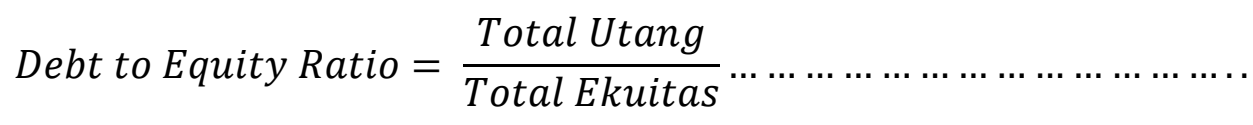

\section{2) Total Asset Turnover (TATO)}

Menurut Brigham and Houston (2014) total asset turnover adalah rasio antara penjualan dengan total aktiva yang mengukur efisiensi penggunaan aktiva secara keseluruhan. Apabila rasio rendah itu merupakan indikasi bahwa perusahaan tidak beroperasi pada volume yang memadai bagi kapasitas investasinya. Menurut Kasmir (2014) total asset turnover adalah rasio pengelolaan aktiva terakhir mengukur perputaran seluruh aset perusahaan dan dihitung dengan membagi penjualan dengan total asset dan mengukur berapa jumlah penjualan yang diperoleh dari tiap rupiah aktiva. Apabila perusahaan tidak menghasilkan volume usaha yang cukup untuk ukuran investasi sebesar total aktibanya, maka penjualan harus ditingkatkan. Rumus untuk mencari total asset turnover adalah sebagai berikut:

$$
\text { Total Asset Turnover }(\text { TATO })=\begin{gathered}
\text { penjualan } \\
\text { Total aset }
\end{gathered}
$$

\section{3) Net profit margin (NPM)}

Menurut Brigham dan Houston (2014) margin laba (net profit margin) adalah rasio yang digunakan untuk mengukur margin laba atas penjualan. Hal ini dihitung dengan membagi laba bersih dengan penjualan bersih. Menurut Keown (2012) margin laba bersih (Net Profit Margin) merupakan kemampuan perusahaan untuk menghasilkan keuntungan 
dibandingkan dengan penjualan yang dicapai. Rumus untuk mencari return on asset adalah sebagai berikut:

$$
\text { Net profit margin }(N P M)=\frac{\text { Laba bersih }}{\text { Penjualan }}
$$

\section{Rerangka konseptual}

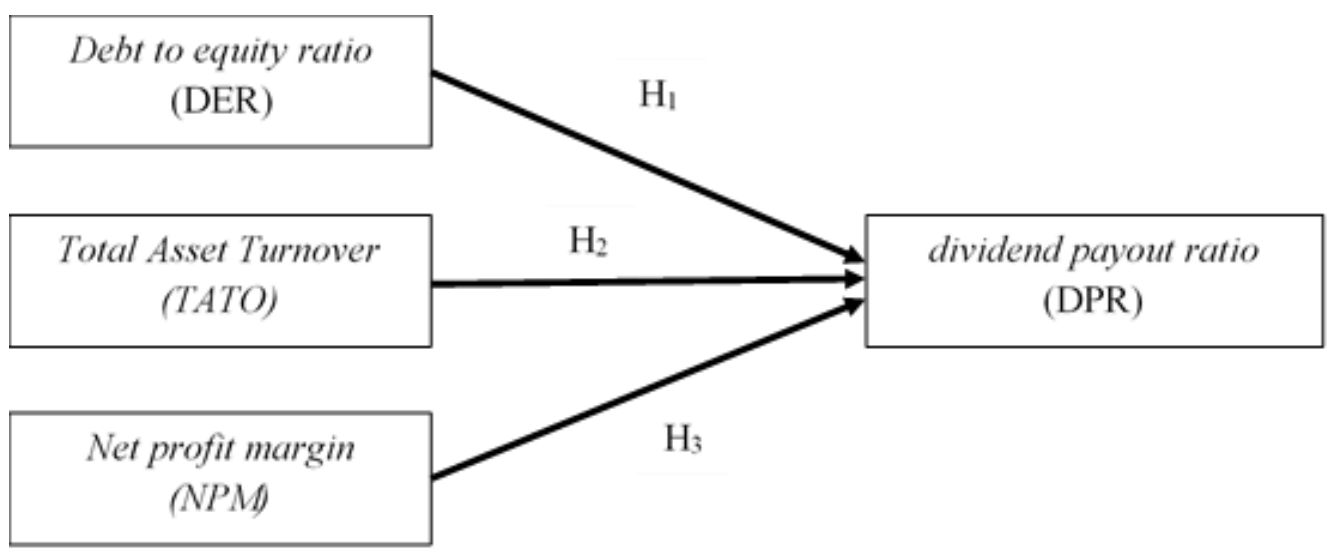

Gambar 1. Rerangka Konseptual

Sumber: berbagai sumber diolah (2018)

\section{Hipotesis}

Menurut Sugiyono (2014) hipotesis penelitian merupakan dugaan sementara yang digunakan sebelum dilakukannya penelitian. Hipotesis penelitian adalah jawaban sementara terhadap masalah yang diteliti, dimana kebenarannya perlu diuji secara empiris. Hipotesis penelitian ini adalah sebagai berikut:

1) $\mathrm{H}_{1}$ : Debt to Equity Ratio (DER) berpengaruh negatif dan signifikan terhadap dividend payout ratio (DPR).

2) $\mathrm{H}_{2}$ : Total Asset Turnover (TATO) berpengaruh positif dan signifikan terhadap dividend payout ratio (DPR).

3) $\mathrm{H}_{3}$ : Net profit margin (NPM) berpengaruh positif dan signifikan terhadap dividend payout ratio (DPR).

\section{METODE PENELITIAN}

\section{Desain Penelitian}

Desain penelitian yang digunakan adalah penelitian kausal. Menurut Sugiyono (2014) penelitian kausal merupakan penelitian untuk mengetahui pengaruh antara satu arah atau lebih variabel bebas (independent variabel) terhadap variabel terikat (dependent variabel), yaitu untuk mengetahui pengaruh variabel Currrent ratio (CR), Return on asset (ROA), Debt to Equity Ratio (DER) dan Sales Growth terhadap Dividend Payout Ratio (DPR). sub sektor farmasi dan kosmetik yang terdaftar di Bursa Efek Indonesia periode 2012-2016.

\section{Definisi dan Operasionalisasi Variabel}


Menurut Sugiyono (2014) variabel adalah segala sesuatu yang berbentuk apa saja yang ditetapkan oleh peneliti untuk dipelajari sehingga diperoleh informasi tentang hal tersebut, kemudian ditarik kesimpulannya.

Variabel dependen

Variabel dependen adalah variabel yang menjadi fokus utama dalam penelitian ini. Variabel ini sering disebut sebagai variabel output, criteria, konsekuen. Dalam bahasa Indonesia disebut juga sebagai variabel terikat. Variabel dependen yang digunakan dalam penelitian ini adalah kebijakan dividen (Y) yang diukur dengan dividend payout ratio (DPR). Menurut Bringham dan Houston (2014) Dividend Payout Ratio (DPR) adalah persentase laba yang dibayarkan dalam bentuk dividen atau rasio antara laba yang dibayarkan dalam bentuk dividen dengan total laba yang tersedia bagi pemegang saham. Dividend payout ratio didefinisikan sebagai besarnya rasio yang harus ditentukan perusahaan untuk membayar dividen kepada para pemegang saham setiap tahun yang dilakukan berdasarkan besar kecilnya laba berseih setelah pajak. Dividend payout ratio merupakan indikasi atas persentase jumlah pendapatan yang diperoleh yang didistribusikan kepada pemilik atau pemegang saham dalam bentuk kas. Secara matematis rumus dividend payout ratio (DPR) dapat dirumuskan sebagai berikut:

$$
\text { Dividend Payout Ratio }=\frac{\text { Dividen per saham }}{\text { Laba per saham } \ldots \ldots \ldots \ldots \ldots \ldots \ldots \ldots \ldots \ldots \ldots \ldots \ldots}
$$

Variabel independen

1) Debt to Equity Ratio (DER)

Menurut Brigham dan Houston (2014) Debt to Equity Ratio adalah Rasio yang menggambarkan perbandingan utang dan ekuitas dalam pendanaan perusahaan dan menunjukan kemampuan modal sendiri perusahaan tersebut untuk memenuhi seluruh kewajibannya. Menurut Keown (2011) menjelaskan bahwa Debt to Equity Ratio menujukkan perbandingan antara utang dengan modal sendiri, sedangkan menurut Fahmi (2009) mendefinisikan Debt to Equity Ratio adalah rasio yang menggambarkan perbandingan utang dan ekuitas dalam pendanaan perusahaan dan menujukkan kemampuan modal sendiri perusahaan tersebut untuk memenuhi seluruh kewajibannya.Secara matematis rumus Debt to Equity Ratio (DER) dapat dirumuskan sebagai berikut:

$$
\text { Debt to Equity Ratio }=\frac{\text { Total Utang }}{\text { Total Ekuitas }}
$$

\section{2) Total Asset Turnover (TATO)}

Menurut Brigham and Houston (2014) total asset turnover adalah rasio antara penjualan dengan total aktiva yang mengukur efisiensi penggunaan aktiva secara keseluruhan. Apabila rasio rendah itu merupakan indikasi bahwa perusahaan tidak beroperasi pada volume yang memadai bagi kapasitas investasinya. Menurut Kasmir (2014) total asset turnover adalah rasio pengelolaan aktiva terakhir mengukur perputaran seluruh aset perusahaan dan dihitung dengan membagi penjualan dengan total asset dan mengukur berapa jumlah penjualan yang diperoleh dari tiap rupiah aktiva. Apabila perusahaan tidak menghasilkan volume usaha yang cukup untuk ukuran investasi sebesar total aktibanya, maka penjualan harus ditingkatkan. Rumus untuk mencari total asset turnover adalah sebagai berikut: 
Total Asset Turnover $($ TATO $)=$

Total aset

3) Net profit margin (NPM)

Menurut Brigham dan Houston (2014) margin laba (net profit margin) adalah rasio yang digunakan untuk mengukur margin laba atas penjualan. Hal ini dihitung dengan membagi laba bersih dengan penjualan bersih. Menurut Keown (2012) margin laba bersih (Net Profit Margin) merupakan kemampuan perusahaan untuk menghasilkan keuntungan dibandingkan dengan penjualan yang dicapai. Rumus untuk mencari return on asset adalah sebagai berikut:

$$
\text { Net profit margin }(N P M)=\frac{\text { Laba bersih }}{\text { Penjualan }}
$$

\section{Populasi dan Sampel Penelitian}

Menurut Sugiyono (2014) populasi adalah wilayah generalisasi yang terdiri atas obyek/subyek yang mempunyai kualitas dan karakteristik tertentu yang ditetapkan oleh peneliti untuk dipelajari dan kemudian ditarik kesimpulannya. Populasi dalam penelitian ini adalah perusahaan industri dasar dan kimia yang terdaftar dalam Bursa Efek Indonesia periode 20122016 dengan kriteria memiliki data lengkap setiap tahun, selamat tahun pemagatan perusahaan menghasilkan laba, dan data bersifat normal sesuai dengan variabel dependen dan independen, sehingga jumlah populasi sebanyak 10 perusahaan selama 5 tahun pengamatan. Menurut Sugiyono (2014) sampel adalah bagian dari jumlah dan karakteristik yang dimiliki oleh populasi. Metode yang digunakan adalah sampel jenuh yang bertujuan untuk mendapatkan sampel yang sesuai dengan populasi. Sampel dalam penelitian ini berjumlah 10 perusahaan selamat 5 tahun pengamatan, sehingga sampel berjumlah 50 data.

\section{Teknik Pengumpulan Data}

Dalam penelitian ini penulis menggunakan teknik pengumpulan data dengan studi kepustakaan. Jenis data yang digunakan dalam penelitian ini adalah data sekunder. Data sekunder adalah data yang sudah diolah, diperoleh berdasarkan laporan tahunan yang telah diaudit dan dipublikasikan. Menurut Sugiyono (2014) data sekunder adalah sumber data yang secara tidak langsung memberikan data kepada pengumpul data, seperti dokumen. Metode pengumpulan data yang digunakan dalam penelitian ini adalah metode dokumentasi. Metode dokumentasi adalah pengumpulan data dengan dokumen yang dapat berupa laporan keuangan yang telah dikumpulkan dan dipublikasikan. Pengumpulan dari laporan keuangan yang terdapat pada annual report, jurnal-jurnal baik dalam maupun luar negeri serta referensi pendukung lainnya.

\section{Metode Analisis}

Menurut Sugiyono (2014) yang dimaksud dengan analisis data adalah kegiatan setelah data dari seluruh responden terkumpul. Menurut Winarno (2015) metode analisis yang digunakan dalam penelitian ini adalah analisis regresi data panel dengan bantuan software eviews 9. EViews adalah program komputer yang digunakan untuk mengolah data statistika dan data ekonometrika, EViews dapat digunnakan untuk menyelesaikan masalah-masalah yang berbentuk time series, cross section, maupun data panel. Winarno (2015) data panel adalah bentuk khusus dari pooled data. Secara sederhana, pooled data adalah kombinasi antara data time series dan data cross section.

\section{HASIL DAN PEMBAHASAN}




\section{Hasil Statistik Deskriptif}

Tabel 1. Statistik Deskriptif

\begin{tabular}{llccc}
\hline & DP & DE & TATO & NP \\
\hline Mean & 51,4400 & 0.419000 & 1.436200 & 13.42060 \\
Median & 47,0000 & 0.270000 & 1.185000 & 11.79500 \\
Maximum & 112,0000 & 1.600000 & 4.010000 & 28.78000 \\
Minimum & 1,0000 & 0.080000 & 0.530000 & 1.100000 \\
Std. Dev. & 0.401366 & 0.359338 & 0.819903 & 8.919530 \\
& & & & \\
\hline Observations & 50 & 50 & 50 & 50 \\
\hline
\end{tabular}

Sumber: data BEI diolah Eviews 9 (2018)

Berdasarkan kepada tabel 1 di atas, terlihat Dividend Payout Ratio (DPR) memiliki nilai mean sebesar 51,44 dengan nilai tertinggi sebesar 112 dan harga saham terendah sebesar 1 . Debt to Equity Ratio (DER) memiliki nilai mean sebesar 0,419 dengan nilai tertinggi sebesar 1,6 dan nilai terendah sebesar 0,08. Total asset turnover (TATO) memiliki nilai mean sebesar 1,4362 dengan nilai tertinggi sebesar 4,01 dan nilai terendah sebesar 0,53. Net profit margin (NPM) memiliki nilai mean sebesar 13,4206 dengan nilai tertinggi yaitu 28,78 dan nilai terendah sebesar 1,10 .

\section{Hasil Pemilihan Model Data Panel}

Uji fixed effect. Pendekatan fixed effect ini merupakan pendekatan yang paling sederhana untuk mengestimasi parameter model data panel, yaitu dengan mengkombinasikan data cross section dan time series sebagai satu kesatuan dan tanpa melihat adanya perbedaan waktu dan individu. Dari pengolahan Eviews 9.0 didapatkan hasil sebagai berikut:

Tabel 2. Hasil Uji fixed Effect

Dependent Variable: DPR

Method: Pooled Least Squares

Date: 05/02/18 Time: 10:55

Sample: 15

Included observations: 5

Cross-sections included: 10

\begin{tabular}{|l|c|c|c|c|}
\hline \multicolumn{1}{|c|}{ Variable } & Coefficient & Std. Error & t-Statistic & Prob. \\
\hline & & & & \\
\hline DER? & -0.642157 & 0.259364 & -2.475888 & 0.0180 \\
\hline TATO? & 0.060897 & 0.103499 & 2.588388 & 0.0418 \\
\hline NPM? & 0.022724 & 0.010116 & 3.246303 & 0.0307 \\
\hline
\end{tabular}

Cross-section fixed (dummy variables) 


\begin{tabular}{|l|l|l|l|}
\hline & & & \\
\hline Adjusted R-squared & 0.837640 & S.D. dependent var & 0.401366 \\
\hline S.E. of regression & 0.161726 & Akaike info criterion & -0.586933 \\
\hline Sum squared resid & 0.967745 & Schwarz criterion & -0.089807 \\
\hline Log likelihood & 27.67331 & Hannan-Quinn criter. & -0.397624 \\
\hline F-statistic & 32.06657 & Durbin-Watson stat & 2.009804 \\
\hline Prob(F-statistic) & 0.000000 & & \\
\hline
\end{tabular}

Sumber: data BEI diolah Eviews 9 (2018)

Berdasarkan tabel 4.2 hasil uji common effect, di dapat persamaan sebagai berikut: Dividen payout ratio $=\mathrm{C}-2.475888 \mathrm{DER}+2.588388 \mathrm{TATO}+3.246303 \mathrm{NPM}$

Berdasarkan Tabel 2 di atas, dapat dilihat bahwa hasil adjusted $R$-squared sebesar 0,837640 atau 83,764 persen. Sehingga dapat dikatakan bahwa variabel-variabel bebas dalam penelitian ini dapat mempengaruhi variabel terikatnya sebesar 83,764 persen sedangkan sisanya 16,236 persen dijelaskan oleh variable lain di luar penelitian.

\section{Pengujian hipotesis}

Uji t

Berdasarkan Tabel 2 hasil uji random effect yang memuat hasil uji t dengan melihat nilai $t$-statistic dan probabilitas dapat dijelaskan sebagai berikut:

1) Pengaruh Debt to Equity Ratio (DER) terhadap Dividend Payout Ratio (DPR)

Menurut tabel 4.2 variabel Debt to Equity Ratio (DER) berpengaruh negatif dan signifikan terhadap dividend payout ratio (DPR). Menurut Brigham dan Houston (2014) Rasio Debt to Equity Ratio (DER) adalah rasio yang membandingkan jumlah Hutang terhadap ekuitas. Rasio ini sering digunakan para analis dan para investor untuk melihat seberapa besar hutang perusahaan jika dibandingkan ekuitas yang dimiliki oleh perusahaan atau para pemegang saham. Semakin tinggi angka DER maka semakin rendah Dividend Payout Ratio (DPR). Hasil penelitian ini sejalan dengan penelitian Handayani (2010), Raissa (2012), Jeanne dan Martha Esra (2014), Rahmawati (2014), Nangoy, dan Murni (2015) dan Parera (2016) yang menyatakan bahwa DER berpengaruh negatif dan signifikan terhadap Dividend Payout Ratio (DPR).

2) Pengaruh Total Assets Turnover (TATO) terhadap Dividend Payout Ratio (DPR)

Menurut tabel 4.2 variabel Total asset turnover (TATO) berpengaruh positif dan signifikan terhadap dividend payout ratio (DPR). Menurut Brigham dan Houston (2014) Total Assets Turnover (TATO) adalah rasio yang menunjukkan Efisiensi aset perusahaan dalam menunjang kegiatan penjualan dapat diwakili dengan Total Assets Turnover. Rasio ini menunjukkan perputaran total aset diukur dari volume penjualan. Hasil penelitian ini sejalan dengan penelitian Jeanne dan Esra (2014), Marlim dan Arifin (2015) dan Purnami dan Artini (2016) yang menyatakan bahwa TATO berpengaruh positif dan signifikan terhadap Dividend Payout Ratio (DPR).

3) Pengaruh Net profit margin (NPM) terhadap Dividend Payout Ratio (DPR) Menurut tabel 4.2 variabel Net profit margin (NPM) berpengaruh positif dan signifikan terhadap dividend payout ratio (DPR). Menurut Brigham dan Houston (2014) bahwa Net Profit Margin berpengaruh positif terhadap Dividend Payout Ratio. Net Profit Margin berkaitan erat dengan rasio dividen. Apabila tingkat keuntungan perusahaan semakin stabil maka perusahaan dapat memprediksi keuntungan keuntungan dimasa yang akan 
datang dengan ketepatan yang lebih tinggi. Hasil penelitian ini sejalan dengan penelitian Prasetyo dan Sampurno (2013) dan Parera (2016) yang menyatakan bahwa NPM berpengaruh positif signifikan terhadap Dividend Payout Ratio (DPR).

\section{Koefisien determinasi $\left(\mathbf{R}^{2}\right)$}

Berdasarkan Tabel 2 di atas, dapat dilihat bahwa hasil adjuster $R$-squared sebesar 0,837640 atau 83,764 persen. Sehingga dapat dikatakan bahwa variabel-variabel bebas dalam penelitian ini dapat mempengaruhi variabel terikatnya sebesar 83,764 persen sedangkan sisanya 16,236 persen dijelaskan oleh variable lain di luar penelitian.

\section{KESIMPULAN}

\section{Simpulan}

Berdasarkan hasil penelitian serta interpretasi data yang telah dilakukan mengenai Debt to Equity Ratio (DER), Total Asset TurnOver (TATO), dan Net Profit Margin (NPM) terhadap kebijakan Dividend Payout Ratio (DPR) pada industri Metal \& Ceramics yang Terdaftar di Bursa Efek Indonesia tahun 2012 - 2016 maka dapat diambil beberapa kesimpulan sebagai berikut: (1) DER berpengaruh negatif dan signifikan terhadap Dividend Payout Ratio; (2) Total Assets Turnover (TATO) berpengaruh positif dan signifikan terhadap Dividend Payout Ratio; (3) Net Profit Margin (NPM) berpengaruh positif dan signifikan terhadap Dividend Payout Ratio.

\section{Saran}

Berdasarkan pembahasan dan simpulan dalam penelitian ini, maka dapat disampaikan saran sebagai berikut:

1) Bagi perusahaan. Dari hasil penelitian ini diperoleh ROA berpengaruh positif dan signifikan. Hal ini berarti perusahaan harus meningkatkan ROA, karena semakin besar ROA menujukkan kebijakan dividen perusahaan yang semakin baik, yang akan mempengaruhi tingkat kesejahteraan dari investor. ROA yang besar akan berdampak pada tingkat pengembalian investasi (dividend) semakin besar.

2) Bagi Investor. Dari hasil penelitian ini diperoleh nilai signifikansi ROA sebesar 0,063. Hal ini berarti bagi investor (pemegang saham) yang hendak menanamkan modalnya untuk berinvestasi pada sub sektor farmasi dan kosmetik tidak perlu khawatir karena nilai ROA yang berpengaruh signifikan akan berdampak pada tingkat pengembalian investasi (return) semakin besar yaitu pendapatan dividen.

3) Bagi penelitian yang mendatang. Jika dilihat dari Adjusted $R^{2}$ yang tergolong kecil yaitu $20,5740 \%$ maka sebaiknya variabel penelitian ditambahkan, serta juga menambahkan periode penelitian, mengingat investor lebih melihat prediksi jangka panjang dibanding prediksi jangka waktu yang relatif pendek. Dan juga ada baiknya jika menambahkan variabel lainnya seperti return on equity (ROE), cash ratio dan quick ratio, total asset turnover ratio (TATO), earning per share (EPS), free cash flow $(\mathrm{FCF})$, net profit margin (NPM), agar dapat meningkatkan nilai Adjusted $\mathrm{R}^{2}$.

\section{DAFTAR PUSTAKA}


Abdul Rehman, Haruto Takumi. (2012). Determinants of Dividend Payout Ratio: Evidence From Karachi Stock Exchange (KSE). Journal of Contemporary Issues in Business Research, 1(1), 20-27.

Adri, Raja S.S, 2012. Akuntansi Keuangan, Yogyakarta: Graha Ilmu.

Brigham dan Houston, 2010. Dasar-dasar Manjemen Keuangan, Jakarta; Salemba Empat

Baah, Boamah Kofi, Richard Tawiah dan Opoku Febiri Eric. (2014). Industry Sector Determinants of Dividend Policy And Its Effect On Share Price In Ghana. International Journal of Economics, Business and Finance, 2(5).

Budiman, Surya dan Harnovinsah. 2016. Analisis Pengaruh Arus Kas, Leverage, Tingkat Pertumbuhan, Ukuran Perusahaan, Dan Profitabilitas Terhadap Kebijakan Dividen. Jurnal TEKUN, 7(1), 49-61.

Darmadji \& Fakhruddin. (2011). Pasar Modal di Indonesia, edisi 3, Salemba Empat, Jakarta.

Deni, Febrianto Frans, Siti Aisjah Dan Atim Djazuli. (2016). Analisis Variabel-Variabel yang Mempengaruhi Kebijakan Dividen. Jurnal Aplikasi Manajemen (JAM), 14(2).

Eltya, Sandy, Topowijono, dan Devi Farah Azizah. 2016. Pengaruh Leverage, Likuiditas, Profitabilitas Dan Ukuran Perusahaan Terhadap Kebijakan Dividen. Jurnal Administrasi Bisnis (JAB), 1(2).

Fahmi, Irham. 2012. Analisis Laporan Keuangan. Cetakan Ke-2. Bandung: Alfabeta.

Fahmi, I., \& Yovi, L. H. 2011. Teori Portofolio dan Analisis Investasi Teori dan Soal Jawab. Bandung: Alfabeta.

Farida, Ida dan Sunandar. (2015). Pengaruh Cash Ratio, Growth, Debt to Equity Ratio Dan Kepemilikan Publik Terhadap Dividend Payout Ratio Pada Perusahaan Yang Terdaftar Di Bursa Efek Indonesia. Jurnal Fokus Bisnis. 1(2), 24-41.

Halim, Abdul. 2005. Analisis Investasi. Edisi ke 2. Jakarta: Salemba empat.

Hartono, J. (2010). Teori Portofolio dan Analisis Investasi. Edisi keenam. Yogyakarta: BPFE.

Horne, James C. Van \& John M Wachowicz, Jr. (2012). Prinsip-Prinsip Manajemen Keuangan. Edisi Ketiga. Jakarta: Salemba Empat.

Ikatan Akuntan Indonesia. (2014). Pernyataan Standar Akuntansi Keuangan Jakarta: Salemba Empat.

Kasmir. (2012). Analisis Laporan Keuangan. Jakarta: PT. Raja Grafindo Persada.

Keown, Arthur J, et al. (2011). Manajemen Keuangan: Prinsip dan Penerapan. Edisi Kesepuluh. PT Indek: Jakarta.

Khan, Waseem, and Naheed Ashraf. (2014). In Pakistani Service Industry: Dividend Payout Ratio as Function of Some Factors. International Journal of Academic Research in Accounting, Finance and Management Sciences, 4(1), 390-96.

Kurniawan, Esti Rusdiana. Rina Arifati. Dan Rita Ardini. (2016). Pengaruh Cash Position, Debt to Equity Ratio, Return On Asset, Current Ratio, Firm Size, Price Earning Ratio, Dan Total Assets Turn Over Terhadap Dividend Payout Ratio Pada Perusahaan Manufaktur Periode 2007-2014. Journal of Accounting, 1(2), 1-13.

Laim, Wisriati dkk. (2015). Analisis Faktor-Faktor yang Mempengaruhi Dividend Payout Ratio pada Perusahaan yang Terdaftar di Indeks LQ-45 Bursa Efek Indonesia. Jurnal EMBA, 3(1), 1129-1140.

Modigliani, F. dan M. H. Miller. (1963). Taxes and the Cost of Capital: A Correction. American Economic Review, 5(3), 433-43.

Mui, Yong Teck dan Mazlina Mustapha. (2016). Determinants of Dividend Payout Ratio: Evidence from Malaysian Public Listed Firm. Journal of Applied Environmental and Biological Sciences, 1(1)48-54.

Murhadi, Werner R. (2015). Analisis Laporan Keuangan Proyeksi dan Valuasi 
Saham. Jakarta: Salemba Empat.

Rizqia, DwitaAyu, Siti Aisjah and Sumiati. (2013). Effect of Managerial Ownership, Financial Leverage, Profitability, Firm Size, and Investment Opportunity on Dividend Policy and Firm Value. Journal of Finance and Accounting, 4(1), 120-130.

Sugiyono. (2014). Metode Penelitian Pendidikan Pendekatan Kuantitatif, Kualitatif dan $R \& D$. Bandung: Alfabeta.

Sugiyono. Metode Penelitian Kuantitatif, Kualitatif Dan R\&D. (2011). Cetakan k e-13. Penerbit Alfabeta. Bandung.

Swastyastu, Made Wiradharma. Gede Adi Yuniarta. Dan Anantawikrama Tungga Atmadja. 2014. Analisis Faktor-Faktor Yang Mempengaruhi Kebijakan Dividend Payout Ratio Yang Terdaftar Di Bursa Efek Indonesia. E-Journal S1 Akuntansi Universitas Pendidikan Ganesha, 1(1), 1-12.

Tandelilin, E. (2010). Analisis Investasi dan Manajemen Portofolio. Edisi Keenam. Yogyakarta: BPFE UGM.

Topowijono, Amaliya Viya Kartika dan M.G. Wi Endang. (2015). Pengaruh Return on Assets, Return on Equity Dan Assets Growth Terhadap Dividend Payout Ratio. Jurnal Administrasi Bisnis (JAB), 1(2).

Usman, Halim dan Sri Wahyuni Mustafa. (2014). Pengaruh CR, DER dan ROA terhadap Dividend Payout Ratio pada Beberapa Perusahaan Pertambangan yang Terdaftar di BEI (2011-2013). Jurnal Akuntansi, 1(2), 43-47.

Yusuf, Abubakar dan Nasiru Muhammed. (2015). Determinant of Dividend Payout in Nigerian Banking Industry. Scholars Bulletin, 1(9), 253-259. 